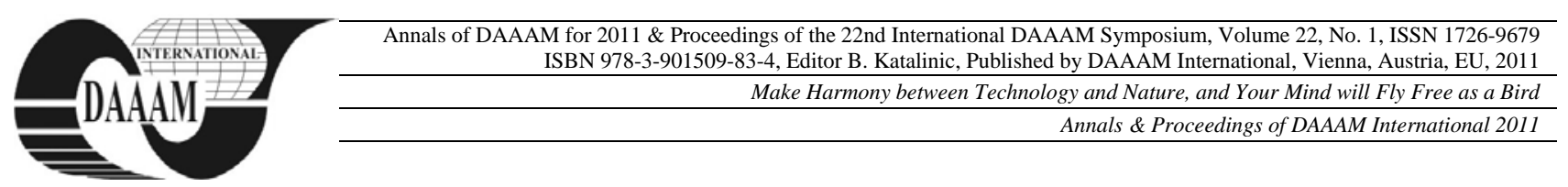

\title{
USE OF E-BUSINESS TO GAIN COMPETITIVE ADVANTAGE
}

\author{
PETRTYL, J[an]
}

\begin{abstract}
This paper is focused on e-business. If implemented properly tools of e-business can make organizations (and even states) more efficient and competitive. Author introduces the topic by definition of e-business framework and mentions difficulties linked to this issue. Then, level of use of e-business in some European countries is described and complmented by links to relevant sources. Some examples of e-business applications follow to illustrate current possibilities of use of ICT to become more competitive. Design of future research forms the final part of this paper.
\end{abstract}

Key words: e-business, development, competitive advantage, efficiency, innovation

\section{INTRODUCTION}

Information and communication technology (ICT) has changed our lives. ICT itself is an "umbrella term that encompasses a wide array of systems, devices and services used for data processing (the information side of ICT) as well as telecommunications equipment and services for data transmission and communication (the communication side)." (European Commission, 2008a, p. 13). It influences the way we work, study, shop, communicate and even how we spend our leisure time. As such, it is sometimes called " 5 th $K o n d r a t i e f f$ " (European Commission, 2005). The role and usefulness of ICT has been very well illustrated on Information society statistics conceptual model (OECD, 2009). "ICT is commonly considered to be a general-purpose technology, as all sectors of the economy use information in their production process." (OECD, 2003, p. 23). It is necessary to differ among various kinds of use of ICT to see more sharply how it can improve the way (not only) companies perform various tasks. It is a very exciting and important challenge to find out, and if possible also measure, how exactly ICT can contribute to economic competitiveness of firms in different states and sectors.

\section{E-BUSINESS}

\subsection{Definition}

The term "e-business" is nowadays very frequently used. It is needed to define it precisely to avoid misunderstandings. Some authors consider terms "e-business" and "e-commerce" to have the same meaning. For purpose of this paper, however, both these terms have specific senses. Different authors use different definitions of e-business. To illustrate this, some examples follow. "The use of information and communication technology (ICT) in business” (Prieger \& Heil in Lee, 2010, p. $12)$, "E-business is the relocation of internal and external business processes to the Internet.” (IBM in Matthewson, 2002, p. 3), "E-business is a term used to describe businesses run on the Internet, or utilizing Internet technologies to improve the productivity of a business. In a more general sense, the term may be used to describe any form of electronic business-that is to say any business which utilizes information technology.” (Kar, 2009, p. 2), "Electronic business is conducting core business activities in a way that is enabled by the integrated use of information technology for processing and communication of information.” (Grefen, 2010, p. 3). Subjectively, the best definition of e-business, that provides wide variety of possible applications, is "Automated business processes (both intra- and inter-firm) over computer mediated networks. E-business covers the full range of e-transactions as well as collaborative business processes, such as collaborative online design processes which are not directly transaction-focused.” (OECD in European Commission, 2010b, p. 174).

\subsection{Use of e-business}

Although it is well known that ICT can significantly improve organizations' performance there are some very important issues which researchers should take into consideration. "The adoption and use of ICT per se does not automatically induce innovations. However, ICT can contribute indirectly to firms' performance by enabling them to improve labor productivity, rethink processes and develop new products." (European Commission, 2008a, p. 21). "ICT has positive impacts on firms' performance and productivity, but that benefits occur primarily, or only, when accompanied by other changes and investments (for example, where skills have been improved and organizational changes have been introduced).” (OECD, 2008, p. 11). There are different possible application areas for e-business technologies. The main ones are: (1) ICT network, (2) e-integration of internal processes, (3) e-procurement and supply chain integration, and (4) emarketing and sales. Large firms are leaders in e-business adoption, followed by medium, small and micro companies (European Commission, 2008b). To illustrate the importance of proper use of ICT and necessary supportive actions linked to this issue, see this example_-'The effect of IT investment on productivity is much larger in US subsidiaries in the United Kingdom than in domestic firms (...); the difference is big enough to explain most of the advantage of US firms operating in the United Kingdom. This is assumed to be due to 'US management practices' which are thought to better use of the information which ICT generates.“ (OECD, 2008, p. 12).

\subsection{Support for e-business applications}

Level of use of e-business differs from state to state. Especially in the European Union, implementation of ICT in firms is of great importance. Although some theories postulate that it is necessary to let market forces form the environment completely freely, it may be very useful to have a support for certain changes "from above". To assist companies DirectorateGeneral for Enterprise and Industry has introduced an advanced tool to help firms to deal with issues of ICT and provides an ebusiness guideline (E-business guide for SMEs). This guide, in addition to its other helpful components, aggregates offers from ICT market supply side. There are also other policies, such as i2010 Strategic Framework etc. (Sonntagbauer, 2011). Alongside this kind of support, states have their own ways to help companies and other organizations to profit from e- 
business-e.g. Estonia, Denmark, Finland, and other states (European Commission, 2010a).

\subsection{Readiness to benefit from e-business}

The Economist Intelligence Unit gives an excellent opportunity to see how prerequisites for successful use of ebusiness are accomplished. Specifically, experts evaluate countries (totally 70 states) and consider five categories with different weights to determine the final score. Concretely, these categories are: (1) connectivity and technology infrastructure, (2) business environment, (3) social and cultural environment, (4) legal environment, (5) government policy and vision, and (6) consumer and business adoption.

The top-scoring countries of year 2010 were: (1) Sweden, (2) Denmark, and (3) United States (The Economist Intelligence Unit, 2010).

\subsection{Practical examples of e-business applications}

Utilizations of e-business can be seen in both, for-profit and non-profit organizations as well as in case of governmental subjects. There are many examples of good practice to draw inspiration how a successful e-business solution can contribute to enhance firm's performance.

Enterprise resource planning, mobile applications, tools of e-marketing or customer relationship management system are just modest examples from a wide range of applicable ebusiness solutions (European Commission, 2009).

\section{CONCLUSION}

E-business is the crucial element that can significantly enhance (not only) organization's performance. From both, theoretical and practical points of view, it is indispensable to define the term properly. Otherwise it may be very easy to lose solid ground for research. It is of great importance to measure how ICT can improve and shift organizational competitiveness. Level of so called e-readiness (in other words level of edevelopment) differs among countries and it pays off to watch it and evaluate it. Because e-business covers very broad range of possible applications which can vary from sector to sector, the best results can be achieved by separate analysis of particular e-business applications. Based on this approach, it is possible to find common signs of excellent implementation and thus find a way to succeed.

\subsection{Further research}

Further research in this domain is an object of author's dissertation thesis. It is focused on "Use of e-business to gain competitive advantage”. The main research aims are: (1) to theoretically introduce the issues of e-business and opportunities this domain gives to businesses in a detailed way, (2) to forecast and critically assess key future trends in the field of e-business, and (3) to find out how successful companies from a selected sector use and profit from e-business applications. The research will be focused especially on conditions of the Czech Republic (where improvements in ICT applications are needed), but also examples of good practice from abroad will be provided for discussion.

Methods of qualitative (case studies, Delphi, consultations with specialists) and quantitative (statistical analysis based on a survey, hypothesis testing) research will be used.

Current work progress includes unfinished theoretical part of the thesis. Research based on Delphi method is about to start in fall 2011. Its preparation phase (aimed to find and involve experts in the research) started in April 2011.

After completion of the theoretical part of the thesis and after three stages of the Delphi method, a practically focused survey (based on questionnaires, complemented by interviews and case studies) will follow. It will be aimed to find out how companies from selected branch use e-business and how its implementation has made them more competitive. Exact mathematical tools will be used in this part of the research.

Added value of the research will consist of several elements: (1) as far as the author knows, not much work of this kind has been done in the Czech Republic yet, (2) majority of activities will be done in co-operation with firms, so that academic and private sector will be involved, (3) based on gained results and examples of good practice, a roadmap to successful use of ICT (reflecting both, actual- and upcoming trends and containing also new theoretical knowledge) will be provided to companies for use.

\subsection{Research limitations}

It is not possible to describe in detail all conceivable applications of e-business in research of this kind. Thus, ebusiness models from one sector may be narrow. Therefore thorough selection of target sector, hypotheses formulation, and performance measurement model selection are of great importance. Moreover, ICT is a very quickly developing field and e-business projects often contain relatively great amount of risk or even uncertainty. Also specialists' opinions acquired by use of Delphi method might not correspond together.

\section{REFERENCES}

European Commission (2010a). E-Business Support Network for SMEs (eBSN) 2003-2009, DG Enterprise and Industry, Brussels

European Commission (2010b). ICT and e-Business for an Innovative and Sustainable Economy, DG Enterprise and Industry, ISBN 978-92-79-14682-4, Brussels

European Commission (2009). Learning From Peers/eBusiness cases, DG Enterprise and Industry, Brussels

European Commission (2008a). An Economic Assessment of ICT Adoption and its Impact on Innovation and Performance, DG Enterprise and Industry, Berlin/Brussels

European Commission (2008b). eBusiness Guide for SMEs, DG Enterprise and Industry, ISBN 13-978-92-79-08808-7, Stuttgart/Brussels

European Commission (2005). A Guide to ICT Usage Indicators, DG Enterprise and Industry, Bonn/Brussels

Grefen, P. (2010). Mastering E-Business, Routlege, ISBN 9780-415-55787-0, New York

Kar, A.K. (2009). eBusiness Enablement: Implications for Business Strategy, Available from: http://papers.ssrn.com/sol3/papers.cfm?abstract_id=143243 3 Accessed: 2011-05-17

Matthewson, J.A. (2002). e-Business: A Jargon-Free Practical Guide, Butterworth-Heinermann, ISBN 0-7506-5293-4, Oxford

OECD (2009). Guide to Measuring Information Society, WPIIS, Paris

OECD (2008). Measuring the Impacts of ICT Using Official Statistics, WPIIS, Paris

OECD (2003). ICT and Economic Growth: Evidence from OECD Countries, Industries and Firms, WPIIS, ISBN 9264-10128, Paris

Prieger, J.E.; Heil, D. (2010). The Microeconomic Impacts of E-Business on the Economy, In: Encyclopedia of EBusiness Development and Management in the Global Economy, Lee, I., pp. 12-22, Business Science Reference, ISBN 978-1-61520-612-4, Hershey

Sonntagbauer, P. (2011). E-Business, emerging trends in the European Union, Communications in Computer and Information Science, Vol. 83 CCIS, pp. 40-50, ISSN 1865-0929

The Economist Intelligence Unit (2010). Digital economy rankings 2010, Available from: http://www935.ibm.com/services/us/gbs/bus/html/ibvdigitaleconomy2010.html Accessed: 2011-06-17 